\title{
Psikoedukasi terhadap kecemasan orang tua pasien yang menjalani pengobatan thalasemia mayor
}

\author{
Octa Reni Setiawati ${ }^{1}$, Nurseha², Teguh Pribadi ${ }^{3}$
}

\begin{abstract}
${ }^{1}$ Fakultas Psikologi Universitas Malahayati Bandar Lampung. Email: ores.survive@gmail.com 2Unit Promosi Kesehatan Rumah Sakit (PKRS) Rumah Sakit Umum Daerah dr H. Bob Bazar SKM Kabupaten Lampung Selatan. Email: nursehaskm@ymail.com ${ }^{3}$ Fakultas Kedokteran Program Studi IImu Keperawatan Universitas Malahayati Bandar Lampung Email: teguh@malahayati.ac.id
\end{abstract}

\section{Abstract \\ Psychoeducation for anxiety in parent: Impact of family member with thalassemia major undergoing treatment in Lampung-Indonesia}

Background: There were 120 and 158 thalassemia patients hospitalized at Dr. Abdul Moeloek General Hospital in Bandar Lampung City in 2016 and 2018 respectively. Major thalassemia is a genetically hereditary disease which is suffered for a lifetime and non-healable. This condition can cause psychosocial effect on parents of thalassemia patients. The anxiety among the parents is mainly caused by the continuous medication and care for lifetime.

Purpose: The objective of this study was to examine the effect of psycho-education (FGD Audiovisual) towards the anxiety on parents of thalassemia patients.

Methods:This was a quantitative study with quasi experiment method. The design was non-equivalent control group. The samples were 60 people.

Results: The univariate analysis was conducted on the frequency distribution while the bivariate analysis was through t-test dependent. At last, the multivariate was analyszed with Anova Post-hoc. The result indicated that there were significant relations among Focus Group Discussion (FGD) $(p=0.000)$, audiovisual $(p=0.001)$, control group $(p=$ 0.530). The multivariate revealed that the FGD intervention had bigger influence on reducing anxiety among parents of major thalassemia patients than the audiovisual. In order to reduce anxiety among parents of thalassemia patients, the health workers should expose them with FGD (Forum Group Discussion) psycho-education.

\section{Keywords: Psycho-education; Audiovisual; Anxiety}

Pendahuluan: Jumlah penderita di Bandar Lampung yang mendapat perawatan di RSUD Dr.H.Abdul Moeloek tahun 2016 berjumlah 120 orang dan tahun 2018 berjumlah 158 orang. Thalasemia mayor adalah penyakit genetik yang diderita seumur hidup, tidak bisa sembuh, hal ini akan menimbulkan dampak psikososial bagi orang tua penderita thalasemia karena pengobatan dan perawatan yang terus menerus dan seumur hidup, salah satu dampak psikososial adalah kecemasan maka diperlukan salah satu pelayanan kesehatan yang ada dalam Pyramid of Family Care yaitu Psikoedukasi.

Tujuan: Penelitian untuk mengetahui pengaruh psikoedukasi (FGD, Audiovisual) terhadap kecemasan orangtua pasien thalasemia.

Metode: Jenis penelitian kuantitatif dengan desain eksperimen semu (quasi eksperiment), rancangan penelitian yang digunakan adalah Non equivalent control group desaign. Sampel dalam penelitian ini berjumlah 60 orang. Analisis data univariate dengan distribusi frekuensi, bivariat dengan uji t-test dependent dan analisis lanjutan dengan Anova posthoc.

Hasil: Diketahui bahwa terdapat hubungan signifikan antara Focus Group Discussion (FGD) ( $p=0,000)$, Audiovisual $(p=0,001)$, Kelompok kontrol $(p=0,530)$. Hasil analisis multivariat menunjukkan intervensi $F G D$ yang lebih besar pengaruhnya dalam menurunkan kecemasan orang tua pasien thalasemia mayor dibandingkan dengan audiovisual. Untuk menurunkan kecemasan orangtua pasien thalasemia untuk meberikan psikoedukasi dengan intervensi Focus Group Discussion (FGD).

\section{Kata Kunci: Psikoedukasi; Focus Group Discussion; Audiovisual; Kecemasan}


Psikoedukasi terhadap kecemasan orang tua pasien yang menjalani pengobatan thalasemia mayor

\section{PENDAHULUAN}

Thalasemia merupakan penyakit hemolitik kronik karena kelainan genetik yang diturunkan secara autosomal resesif. Thalasemia memiliki karakteristik berupa penurunan atau pengurangan produksi rantai globin, sehingga menyebabkan eritrosit yang mudah rapuh, dan mengakibatkan anemia dengan berbagai macam derajatnya (Ganie, 2016). Penyakit thalasemia dijelaskan pertama kali oleh Cooley (1925), semula ditemukan di sekitar Laut Tengah, menyebar sampai mediteran, Afrika, Timur Tengah, India, Asia Tenggara termasuk Indonesia (Rund, 2016). Berdasarkan manifestasi klinisnya thalasemia dibagi menjadi tiga kelompok yaitu thalasemia mayor yang membutuhkan transfusi darah seumur hidup, thalasemia minor tanpa gejala dan thalasemia intermedia (Shodikin, Suwarniaty, \& Nugroho, 2016). Berdasarkan data Word Health Organization (WHO) sekitar $5 \%$ dari seluruh populasi dunia adalah karier Thalasemia (Rezeki, Nurhayati, Supriyanto, \& Kartikasari, 2012). Untuk asia tenggara menurut Thavorncharoensap, pembawa sifat thalasemia mencapai 55 juta orang (Mariani, Rustina, \& Nasution, 2014).

Indonesia merupakan salah satu negara yang memiliki penduduk pembawa thalasemia, di mana frekuensi pembawa thalasemia di Indonesia adalah sekitar 3-8\%. Di beberapa daerah mencapai 10\%, artinya bahwa 3-8 dari 100 penduduk merupakan pembawa gen thalasemia, dimana angka kelahiran rata rata $23 \%$ dengan jumlah populasi penduduk sebanyak 240 juta,diperkirakan akan lahir 3000 bayi pembawa gen thalasemia tiap tahunnya (Ray, Rahmawati,\& Andhini, 2019). Pasien thalasemia mendapatkan terapi berupa transfusi darah sebab pada pasien ini timbul manifestasi berupa anemia akibat ketidakmampuan tubuh untuk mengompensasi penurunan hemoglobin yang terjadi karena proses eritropoiesis tidak berjalan dengan efektif. Hal tersebut bila tidak ditangani dengan baik, dapat menyebabkan wajah pucat, hepatosplenomegali, keterlambatan pubertas, gangguan pertumbuhan serta ketidakmampuan untuk melakukan aktivitas sehari-hari (Moeryono, Subroto, \& Suryansyah, 2012).

Rumah Sakit Umum Daerah Dr. H. Abdul Moeloek adalah rumah sakit tipe $B$ yang terletak di Bandar Lampung dan merupakan RS rujukan tertinggi untuk Rumah Sakit di 15 kabupaten/kota di Provinsi Lampung dan merupakan pusat rujukan thalasemia di provinsi Lampung, dimana trend penderita thalasemia dari tahun ketahun mengalami kenaikan, tahun 2014 berjumlah 87 orang dan tahun 2015 tercatat 102 orang, meningkat pada tahun 2016 tercatat 120 orang (Pranajaya, \& Nurchairina, 2017).

Thalasemia mayor merupakan penyakit kronik yang secara genetik diturunkan dari kedua orang tuanya, diderita seumur hidup hal ini akan membawa banyak masalah baik bagi penderita thalasemia maupun keluarga (Bulan, 2009). Penyakit thalasemia mayor memerlukan pengobatan dan perawatan yang terus menerus seperti tranfusi dan obat kelasi besi. Kondisi kronik ini akan berpengaruh terhadap kondisi fisik, psikis dan sosial bagi penderita maupun keluarga. Penderita thalasemia sering pusing, wajah pucat, badan sering lemas, sukar tidur, nafsu makan hilang dan pembesaran limpa dan hati, hal ini akan mempengaruhi gangguan fisik berupa gangguan tumbuh kembang. Sampai saat ini di indonesia terapi utama adalah tranfusi darah, namun dampak tranfusi darah akan menyebabkan penimbunan besi di organ-organ seperti hati dan jantung. Penyakit kronik akan mengakibatkan gangguan psikososial salah satu gangguan psikososial adalah kecemasan (ansietas) (Nurhasanah, 2017).

Kecemasan adalah gangguan alam perasaan (affective) yang ditandai dengan perasaan ketakutan atau kekwatiran yang mendalam dan berkelanjutan tidak mengalami gangguan dalam menilai realitas (Reality Testing Ability/ RTA masih baik) kepribadian masih tetap utuh, prilaku dapat terganggu tetapi masih dadlam batas normal (Hawari, 2001). Salah satu upaya yang dapat dilakukan untuk mengurangi masalah psikososial yang dialami oleh orangtua penderit thalasemia Adalah psikoedukasi. Psikoedukasi salah satunya adalah melatih untuk mempelajari aneka Life skills atau keterampilan hidup. Psikoedukasi dimaknai sebagai suatu usaha untuk mengembangkan keterampilan hidup melalui program terstruktur, yang meliputi keterampilan mendengarkan, kemampuan memecahkan masalah dam membuat rencana, kemampuan mengelola kecemasan, kemampuan menjalani aneka transisi kehidupan yang penting (Supratiknya, 2008).

Octa Reni Setiawati' Fakultas Psikologi Universitas Malahayati Bandar Lampung. Email: ores.survive@gmail.com Nurseha ${ }^{2}$ Unit Promosi Kesehatan Rumah Sakit (PKRS) Rumah Sakit Umum Daerah dr H. Bob Bazar SKM Kabupaten Lampung Selatan. Email: nursehaskm@ymail.com

Teguh Pribadi ${ }^{3}$ Fakultas Kedokteran Program Studi llmu Keperawatan Universitas Malahayati Bandar Lampung Email: teguh@malahayati.ac.id 
Psikoedukasi terhadap kecemasan orang tua pasien yang menjalani pengobatan thalasemia mayor

Psikoedukasi adalah merupakan suatu tindakan yang diberikan pada individu dan keluarga untuk memperkuat strategi koping atau suatu cara khusus dalam menangani kesulitan perubahan mental. Psikoedukasi dapat dilaksanakan di berbagai tempat pada berbagai kelompok atau rumah tangga. Tindakan psikoedukasi memiliki media berupa catatan seperti poster, booklet, leaflet,video dan beberapa eksplorasi yang diperlukan (Soeb, 2011).

Berdasarkan data dari POPTI propinsi Lampung menyatakan jumlah pasien thalasemia di Provinsi Lampung hingga tahun 2017 sebanyak 135 orang. Sedangkan pada tahun 2018 jumlah pasien thalasemia bertambah sebanyak 158 orang, terjadi peningkatan penderita thalasemia di RSUD Dr.H.Abdul Moeloek Propinsi Lampung.

\section{METODE PENELITIAN}

Penelitian kuantitatif dengan desain eksperimen semu (quasi eksperiment), rancangan penelitian yang digunakan Non equivalent control group desaign dengan tujuan untuk mengetahui pengaruh psikoedukasi terhadap kecemasan orang tua penderita thalasemia mayor yang ada di RSUD Dr. H. Abdul Moeloek Provinsi Lampung Tahun 2018. Penelitian ini menggunakan tiga kelompok yang diberi pelakuan psikoedukasi berbeda yaitu dengan Diskusi kelompok, audio visual dan kelompok kontrol yang tidak diberikan intervensi.

Penelitian ini dilaksanakan pada bulan Desember 2018 dengan populasi seluruh orang tua penderita thalasemia mayor yang dirawat di RSUD Dr.H.Abdul Moeloek Propinsi Lampung dan terdapat 158 penderita. Teknik pengambilan sampel menggunakan cara purposive sampling yang sesuai dengan kriteria inklusi dan ekslusi. Besar sampel dalam penelitian ini adalah 20 Responden dari masing -masing kelompok, jumlah seluruh sampel berjumlah 60 Responden. Confidence Interval yang digunakan menggunakan level kepercayaan sebesar 95\%.

Instrumen Pengumpulan data menggunakan kuesioner yang meliputi data demografi yang berhubungan dengan karakteristik responden meliputi kode/nomor responden, usia responden, pendidikan, pekerjaan, penghasilan keluarga dan lama sakit thalasemia mayor. Untuk mengukur tingkat kecemasan keluarga menggunakan modif , menyesuaikan kuesioner kecemasan dari Hamilton Rating Scale for anxiety (HRS-A). Merupakan alat untuk mengukur derajat kecemasan, yang terdiri dari 14 kelompok gejala yang masing-masing kelompok dirinci lagi dengan gejala-gejala yang lebih spesifik. Adapun cara penilaian tingkat kecemasan menggunakan skala HARS yang terdiri dari 14 kelompok gejala. Responden yang sesuai kriteria inklusi kemudian dibagi menjadi tiga kelompok (Focus Group Discussion (FGD), Audiovisual dan kelompok kontrol).

Pelaksanaan intervensi dengan Focus Group Discussion (FGD), dimulai dengan Pembukan; penjelasanan tujuan diskusi dilanjutkan dengan sesi 1 (30 menit): menggali pengalaman, kesulitankesulitan memiliki anak dengan thalassemia mayor, kiat-kiat mengatasi masalah yang dihadapi; Sesi 2 (20 menit): menggali informasi harapan orang tua penderita thalassemia sehingga orang tua tidak merasa cemas atau was-was terhadap masa depan anaknya. Penutup (5 Menit).

Pelaksanaan intervensi dengan menggunakan Audiovisual; Pembukaan (5 menit) penjelasan tentang isi audiovisual yang akan diputar, Sesi 1 (10 menit) berisi video tentang thalasemia, Sesi 2 (20 menit) berisi video Pengalaman Hidup dengan thalassemia, dan sesi 3 (5 menit) berisi video cara pencegahan penyakit thalassemia, Penutup (5 menit) berisi ucapan terima kasih dan kemanfaatnya.

Pada kelompok kontrol tidak diberikan intervensi, dan semua kelompok dilakukan pre test dan pada hari ke 3 dilakukan post test. Setelah data terkumpul maka data di deskripsikan dan diberikan skor sesuai dengan tingkat kecemasan pre test dan post test yaitu $0-13$ ( tidak ada kecemasan), 14 - 20 ( kecemasan ingan), 21 27( kecemasan sedang), 28 - 41( kecemasan berat ), 42 - 56 (kecemasan berat sekali), selanjutnya ditabulasikan, data dimasukkan dalam tabel frekuensi distribusi dan diinterpretasikan.

Uji statistik yang dilakukan menggunakan uji T Dependen/ berpasangan, Confidental Interval (Cl) yang digunakan adalah $95 \%(a \leq 0,05)$, Analisis Lanjutan dengan menggunakan uji Anova atau Post-Hoc dengan metode Bonferroni.

Octa Reni Setiawati' Fakultas Psikologi Universitas Malahayati Bandar Lampung. Email: ores.survive@gmail.com Nurseha ${ }^{2}$ Unit Promosi Kesehatan Rumah Sakit (PKRS) Rumah Sakit Umum Daerah dr H. Bob Bazar SKM Kabupaten Lampung Selatan. Email: nursehaskm@ymail.com

Teguh Pribadi ${ }^{3}$ Fakultas Kedokteran Program Studi llmu Keperawatan Universitas Malahayati Bandar Lampung Email: teguh@malahayati.ac.id 
HASIL

Tabel 1. Distribusi Responden Berdasarkan Data Demografi ( $\mathrm{N}=60)$

\begin{tabular}{lc}
\hline Variabel & Jumlah \\
\hline Usia & \\
$21-35$ th & 11 \\
Th & 41 \\
$>58$ th & 8 \\
& \\
Jenis kelamin & \\
Laki-laki & 15 \\
Perempuan & 45 \\
& \\
Pendidikan & \\
SD & 8 \\
SMP & 8 \\
SMA & 35 \\
PT & 9 \\
& \\
Pekerjaan & \\
PNS & 2 \\
Swasta & 18 \\
IRT & 40 \\
& \\
Penghasilan & \\
Di atas UMR & \\
Di bawah UMR & 19 \\
\hline
\end{tabular}

Berdasarkan Tabel.1 diperoleh hasil bahwa responden yang terbanyak adalah usia $36-58$ tahun, jenis kelamin responden mayoritas perempuan berjumlah 45 orang, pendidikan terbanyak responden adalah SMA berjumlah 35 orang sedangkan pekerjaan responden yang terbanyak adalah Ibu Rumah Tangga yang dalam arti tidak bekerja atau mendapat penghasilan.

Tabel 2. Perbadaan rata-rata kecemasan sebelum dan sesudah diberikan intervensi

\begin{tabular}{lccc}
\hline Intervensi & Mean & Perbedaan Mean & p-Value \\
\hline Pre FGD & 18,25 & 6,7 & 0,000 \\
Post FGD & 11,55 & & \\
Pre test Audiovisual & 17,25 & 4,85 & 0,001 \\
Post Audio visual & 12,40 & & \\
Pre test kontrol & 18,95 & 0,2 & 0,530 \\
Post Test Kontrol & 18,75 & &
\end{tabular}

Berdasarkan tabel 2 diatas dapat dijelaskan mengenai kelompok yang menggunakan intervensi FGD rata-rata tingkat kecemasan dari 20 responden sebelum di intervensi FGD adalah sebesar 18,25 sedangkan sesudah

Octa Reni Setiawati' Fakultas Psikologi Universitas Malahayati Bandar Lampung. Email: ores.survive@gmail.com Nurseha ${ }^{2}$ Unit Promosi Kesehatan Rumah Sakit (PKRS) Rumah Sakit Umum Daerah dr H. Bob Bazar SKM Kabupaten Lampung Selatan. Email: nursehaskm@ymail.com

Teguh Pribadi ${ }^{3}$ Fakultas Kedokteran Program Studi llmu Keperawatan Universitas Malahayati Bandar Lampung Email: teguh@malahayati.ac.id 
Psikoedukasi terhadap kecemasan orang tua pasien yang menjalani pengobatan thalasemia mayor

diintervensi psikoedukasi dengan FGD menjadi 11,55 terjadi perbedaan mean sebesar 6,7. Hasil uji statistik diperoleh $p$ value sebesar 0,000 , hal ini menunjukan bahwa perbedaan antara dua rata-rata kecemasan sebelum dan sesudah diberikan psikoedukasi dengan FGD adalah signifikan, dengan demikian dapat dinyatakan bahwa pemberian psikoedukasi dengan FGD sangat mempengaruhi terhadap kecemasan pada orang tua pasien thalassemia, pada kelompok yang menggunakan intervensi Audio Visual rata-rata tingkat kecemasan dari 20 responden sebelum diintervensi psikoedukasi metode audio visual adalah sebesar 17,25 sedangkan sesudah diintervensi psikoedukasi metode audio visual menjadi 12,40 terjadi perbedaan mean sebesar 4,85. Hasil uji statistik diperoleh $p$ value sebesar 0,0001 hal ini menunjukan bahwa perbedaan antara dua rata-rata kecemasan sebelum dan sesudah diberikan psikoedukasi metode audio visual adalah signifikan, dengan demikian dapat dinyatakan bahwa pemberian psikoedukasi metode audio visual dapat mempengaruhi tingkat kecemasan, kelompok kontrol rata-rata tingkat kecemasan dari 20 responden sebelum diintervensi psikoedukasi kelompok kontrol adalah sebesar 18,95 sedangkan sesudah diintervensi psikoedukasi kelompok kontrol menjadi 18,75. Hasil uji statistik diperoleh $p$ value sebesar 0,530 , hal ini menunjukan bahwa perbedaan antara dua rata-rata kecemasan sebelum dan sesudah diberikan psikoedukasi kelompok kontrol ada perubahan, maka dapat disumpulkan bahwa ada perubahan kecemasan sebelum dan sesudah diberikan test tanpa diberikan intervensi.

Tabel 3. Hasil Analisis Anova dengan menggunakan Post Hoc dengan Benferoni

\begin{tabular}{llll}
\hline \multicolumn{2}{l}{ Metode Psikoedukasi } & Perbedaan Mean & $p$-value \\
\hline FGD & Audiovisual & 1,85 & 434 \\
& Kontrol & 6,50 & 000 \\
\multirow{2}{*}{ Audiovisual } & FGD & $-1,85$ & 434 \\
& Kontrol & 4,65 & 001 \\
\hline
\end{tabular}

Dari tabel 3. dapat dijelaskan bahwa ada perbedaan pada kelompok FGD dengan kelompok kontrol dengan perbedaan mean sebesar 6,50 dengan $p$ value 0,000 , kelompok selanjutnya adalah kelompok Audio Visual dengan dengan kelompok kontrol sebesar 4.65 dengan $p$ value 0,001. Dapat disimpulkan bahwa metode yang paling baik untuk melihat penurunan kecemasan yaitu metode Focus Group Discussion (FGD).

\section{PEMBAHASAN}

Hasil penelitian ini dapat dijelaskan bahwa kelompok yang menggunakan FGD rata-rata tingkat kecemasan dari 20 responden sebelum di intervensi psikoedukasi dengan FGD adalah sebesar 18,25 sedangkan sesudah diintervensi psikoedukasi dengan FGD menjadi 11,55. Hasil uji statistik diperoleh $\mathrm{p}$ value sebesar 0,000 , hal ini menunjukan bahwa perbedaan rata-rata tingkat kecemasan sebelum dan sesudah diberikan psikoedukasi dengan FGD adalah signifikan, maka dapat disimpulkan bahwa perbedaan kecemasan sebelum dan sesudah diberikan intervensi psikoedukasi dengan FGD adalah berbeda, dengan demikian dapat dinyatakan bahwa pemberian psikoedukasi dengan FGD sangat mempengaruhi terhadap penurunan tingkat kecemasan pada orang tua. Hasil yang signifikan ini sama seperti penelitian sebelumnya yang dilakukan pada anak SMA yang akan menghadapi ujian Nasional (Mukhlis, 2014).

Hasil pada kelompok menggunakan metode Audio Visual rata-rata tingkat kecemasan dari 20 responden sebelum diintervensi psikoedukasi metode audio visual adalah sebesar 17,25 sedangkan sesudah diintervensi psikoedukasi metode audio visual menjadi 12,40. Hasil uji statistik diperoleh $p$ value sebesar 0,0001 , hal ini menunjukan bahwa perbedaan rata-rata kecemasan sebelum dan sesudah diberikan psikoedukasi metode audio visual adalah signifikan. Jadi menonton video tersebut seperti menonton kehidupan responden dengan segala suka dan dukanya, dan itu memang harus dilakukan demi kelangsungan hidup anaknya, terlihat dari raut wajahnya tampak ada rasa lega

Octa Reni Setiawati' Fakultas Psikologi Universitas Malahayati Bandar Lampung. Email: ores.survive@gmail.com Nurseha ${ }^{2}$ Unit Promosi Kesehatan Rumah Sakit (PKRS) Rumah Sakit Umum Daerah dr H. Bob Bazar SKM Kabupaten Lampung Selatan. Email: nursehaskm@ymail.com

Teguh Pribadi ${ }^{3}$ Fakultas Kedokteran Program Studi llmu Keperawatan Universitas Malahayati Bandar Lampung Email: teguh@malahayati.ac.id 
Psikoedukasi terhadap kecemasan orang tua pasien yang menjalani pengobatan thalasemia mayor

dan menerima mempunyai anak thalasemia. Penelitian sebelumnya terhadap 20 responden bahwa ada pengaruh audiovisual terhadap tingkat kecemasan ibu partus kala I. Intervensi audiovisual yang digunakan adalah dengan menonton video gambar bayi -bayi yang lucu, ini dapat menurunkan kecemasan pada ibu kala I persalianan (Risnawati, 2018). Penelitian ini juga didukung oleh penelitian terhadap 15 ibu hamil primigravida pre dan post test dengan menonton proses persalinan normal dapat menurunkan kecemasan ibu primigravida dalam mengahadapi persalinan (Arafah \& Eizar, 2011).

Hasil pada kelompok kontrol rata-rata tingkat kecemasan dari 20 responden sebelum diintervensi psikoedukasi kelompok kontrol adalah sebesar 18,95 sedangkan sesudah diintervensi psikoedukasi kelompok kontrol menjadi 18,75 . Hasil uji statistik diperoleh $p$ value sebesar 0,530, hal ini menunjukan bahwa korelasi antara dua ratarata kecemasan sebelum dan sesudah diberikan psikoedukasi kelompok control tidak ada perubahan yang signifikan dengan demikian dapat dinyatakan bahwa psikoedukasi pada kelompok kontrol tidak mempengaruhi tingkat kecemasan pada orang tua

Hasil Analisis dengan menggunakan uji Anova Post Hoc dapat dijelaskan bahwa ada perbedaan pada kelompok FGD dengan kelompok kontrol dengan perbedaan mean sebesar 6,50 dengan $p$ value 0,001 , kelompok selanjutnya adalah kelompok Audio Visual dengan dengan kelompok kontrol sebesar 4.65 dengan $p$ value 0,001 . Dapat disimpulkan bahwa metode yang paling efektif untuk menurunkan kecemasan yaitu metode Focus Group Discussion (FGD)/Diskusi kelompok terarah karena disini terjadi komunikasi dua arah antara responden dan moderator/narasumber sedangkan audio visual hanya terjadi komunikasi satu arah. Hasil penelitian ini didukung oleh penelitian yang dilakukan mengenai peningkatan pengetahuan ibu tentang pencegahan gizi kurang melalui konseling (Yulyani \& Sari, 2017). Proses konseling dan FGD merupakan pendekatan dengan komunikasi dua arah.

Komunikasi yang efektif apabila terjadi aliran informasi dua arah antara komunikator dan komunikan dan informasi tersebut sama-sama direspon sesuai dengan harapan pengirim, komunikasi mengandung pengertian memberikan informasi, pesan atau gagasan pada orang lain dengan maksud agar orang lain tersebut kesamaam informasi atau pesan atau gagasan dengan pengirim pesan, Komunikasi merupakan tindakan melaksanakan kontak antara pengirim dan penerima dengan tujuan tertentu dimana pengirim dan penerima memeiliki beberapa pengalaman yang sama serta memberi pendapat pada pengalaman yang dikirim oleh pengirim dan diterima dan ditafsirkan oleh penerima (Rahman, 2016). FGD terjadi komunikasi dua arah hal ini dapat mengumpulkan informasi, menghasilkan ide dan pandangan yang lebih luas. Komentar dari responden secara acak dapat memacu reaksi berantai, respon yang beragam sangat mungkin untuk menghasilkan informasi atau ide baru bagi responden serta dapat lebih mendorong responden untuk berpartisipasi mengeluarkan pendapat secara spontan, responden merasa lebih aman, bebas dan leluasa mengekpresikan perasaan dan pikiran (Indrizal, 2014).

Dari hasil perbandingan kedua intervensi didapatkan FGD lebih efektif dibandingkan dengan intervensi audiovisual, hal ini disebabkan FGD lebih komunikatif karena ada komunikasi aktif dua arah sehingga responden dapat bertukar pengalaman, mengungkapkan apa yang menjadi beban atau kendala selama merawat anak penderita thalasemia, dengan bercerita dan mengungkapkan apa yang dirasakan dapat mengurangi kecemasan hal ini sesuai dengan Ali Rahman bahwa komunikasi yang efktif meberikan informasi, pesan atau gagasan pada orang lain dengan tujuan agar terjadi persamaan persepsi dan informasi. Sedangkan audiovisual terjadi komunikasi yang kurang efektif karena tidak terjadi aliran informasi dua arah antara komunikator dan komunikan, informasi tidak dapat direspon sesuai dengan harapan pengirim nformasi, sehingga pesan atau gagasan yang diterima responden tidak dapat diketahui apakah ada kesamaam informasi atau pesan atau gagasan dengan yang harapan pengirim pesan. Karena dalam audiovisual tidak ada komunikasi antara responden dan narasumber hanya menonton video tentang thalasemia dan kehidupan anak dengan thalasemia, sehingga informasi yang didapat sangat tergantung pada sudut pandang responden.

Octa Reni Setiawati' Fakultas Psikologi Universitas Malahayati Bandar Lampung. Email: ores.survive@gmail.com Nurseha ${ }^{2}$ Unit Promosi Kesehatan Rumah Sakit (PKRS) Rumah Sakit Umum Daerah dr H. Bob Bazar SKM Kabupaten Lampung Selatan. Email: nursehaskm@ymail.com

Teguh Pribadi ${ }^{3}$ Fakultas Kedokteran Program Studi llmu Keperawatan Universitas Malahayati Bandar Lampung Email: teguh@malahayati.ac.id 
Psikoedukasi terhadap kecemasan orang tua pasien yang menjalani pengobatan thalasemia mayor

\section{SIMPULAN}

Berdasarkan penelitian dapat diketahui dari 60 responden, usia responden pada kelompok FGD rata-rata adalah 41,8 tahun, kelompok Audio Visual rata-rata adalah 39,3 tahun, sedangkan pada kelompok kontrol rata-rata yaitu 44,6 tahun, jenis kelamin dari ketiga kelompok responden baik FGD, audiovisual dan kontrol yang terbanyak adalah jenis kelamin perempuan, tingkat pendidikan masing-masing kelompok FGD audiovisual dan kelompok kontrol pendidikan responden terbanyak adalah pendidikan SMA, pekerjaan Kelompok FGD, dan kelompok kontrol yang terbanyak adalah Ibu rumah tangga atau tidak bekerja, penghasilan pada kelompok FGD penghasilan responden sebagian besar masih di bawah Upah Minimal Propinsi (UMP).

Hasil penelitian ini membuktikan ada pengaruh psikoedukasi dengan intervensi FGD perbedaan mean sebelum dan sesudah intervensi sebesar 6,7 dengan $P$ Value 0,000 , sedang pada intervensi audio visual terjadi perubahan mean 4,85 dengan p Value 0,001 dan pada kelompok kontrol perubahan mean sebesar 0,2 dengan $p$ Value 0,530 . Dengan demikian dari hasil penelitian ini Psikoedukasi dengan intervensi FGD yang paling berpengaruh terhadap kecemasan orang tua penderita thalasemia dibandingkan dengan audiovisual.

\section{SARAN}

Hasil penelitian ini diharapkan dapat dilanjutkan sebagai bentuk intervensi di rumah sakit yang dapat dijadikan sebagai pedoman dan protap dalam penatalaksanaan gangguan psikososial pada orang tua pasien thalasemia mayor atau penyakit kronis lain, untuk meminimalkan dampak psikologis akibat penyakit thalassemia baik bagi pasien maupun keluarganya. Rumah Sakit dapat memberikan psikoedukasi dengan intervensi FGD untuk menurunkan kecemasan orangtua pasien thalasemia mayor karena intervensi ini terbukti sangat efektif, Perlunya dilakukan penelitian lebih lanjut berkaitan dengan dampak psikososial penyakit thalassemia bagi penderita maupun keluarganya dengan mengembangkan intervensi selain FGD dan audiovisual, perlunya penelitian lebih lanjut faktor-faktor apa saja dari karakteristik orang tua penderita thalasemia yang dapat mempengaruhi tingkat kecemasan orang tua penderita thalasemia

\section{DAFTAR PUSTAKA}

Arafah, C., \& Aizar, E. (2011). Kecemasan ibu primigravinda dalam Menghadapi Persalinan di Klinik $\mathrm{Hj}$. Hadijah Medan setelah menonton video proses persalinan normal. Jurnal: Fakultas Keperawatan, Universitas Sumatera Utara.

Bulan, S. (2009). Faktor-faktor yang berhubungan dengan kualitas hidup anak thalassemia beta mayor factors relating to quality of life children with thalassemia beta major (Doctoral dissertation, Universitas Diponegoro).

Ganie, R. A. (2016). Thalasemia: Permasalahan dan Penanganannya.

Hawari, D. (2001). Manajemen stress, cemas dan depresi. Fakultas Kedokteran Universitas Indonesia.

Indrizal, E. (2014). Diskusi kelompok terarah. Jurnal Antropologi: Isu-Isu Sosial Budaya, 16(1), 75-82.

Mariani, D., Rustina, Y., \& Nasution, Y. (2014). Analisis faktor yang memengaruhi kualitas hidup anak thalassemia beta mayor. Jurnal Keperawatan Indonesia, 17(1), 1-10.

Moeryono, H. W., Subroto, F., \& Suryansyah, A. (2016). Pubertas terlambat pada Anak Thalassemia di RSAB Harapan Kita Jakarta. Sari Pediatri, 14(3), 162-6.

Mukhlis, H. (2014). Pelatihan kebersyukuran untuk menurunkan kecemasan menghadapi ujian nasional pada siswa SMA. Gadjah Mada Journal of Professional Psychology (GamaJPP), 1(3).

Nurhasanah, N. (2017). Pengaruh psikoedukasi terhadap koping orang tua dalam merawat anak dengan Thalasemia Di Kota Banda. Idea Nursing Journal, 8(2), 56-62.

Octa Reni Setiawati' Fakultas Psikologi Universitas Malahayati Bandar Lampung. Email: ores.survive@gmail.com Nurseha ${ }^{2}$ Unit Promosi Kesehatan Rumah Sakit (PKRS) Rumah Sakit Umum Daerah dr H. Bob Bazar SKM Kabupaten Lampung Selatan. Email: nursehaskm@ymail.com

Teguh Pribadi ${ }^{3}$ Fakultas Kedokteran Program Studi llmu Keperawatan Universitas Malahayati Bandar Lampung Email: teguh@malahayati.ac.id 
Psikoedukasi terhadap kecemasan orang tua pasien yang menjalani pengobatan thalasemia mayor

Pranajaya, R., \& Nurchairina, N. (2017). Faktor yang berhubungan dengan kualitas hidup anak thalasemia. Jurnal ilmiah keperawatan sai betik, 12(1), 130-139.

Rahman, A. (2016). Bentuk-bentuk komunikasi dalam pembelajaran. Paedagogia: Jurnal Pendidikan, 5(2), 198-217.

Ray, R. L., Rahmawati, F., \& Andhini, D. (2019, February). Hubungan pengetahuan dan sikap orang tua dengan kualitas hidup anak penderita TALASEMIA. In Seminar Nasional Keperawatan (No. 2, pp. 79-85).

Rejeki, D. S. S., Nurhayati, N., Supriyanto, S., \& Kartikasari, E. (2012). Studi epidemiologi deskriptif talasemia. Kesmas: National Public Health Journal, 7(3), 139-144.

Risnawati, I. (2018). Efek terapi audio visual dan komunikasi terapeutik terhadap tingkat kecemasan ibu inpartu kala i. 2-trik: tunastunas riset kesehatan, 8(1).
Rund, D. (2016). Thalassemia 2016: modern medicine battles an ancient disease. American journal of hematology, 91(1), 15-21.

Shodikin, M. A., Suwarniaty, R., \& Nugroho, S. (2016). Correlation between serum ferritin and cardiac troponin I in major beta thalassemia children. Journal of Tropical Life Science, 6(1), 10-14.

Soep, S. (2011). Pengaruh intervensi psikoedukasi dalam Mengatasi depresi postpartum di sebuah RS di Medan. Majalah Keperawatan Unpad, 13(1).

Supratiknya, A. (2011). Merancang Program dan Modul.

Yulyani, V., \& Sari, F. E. (2017). Perbedaan Pengetahuan Ibu Tentang Pencegahan Gizi Kurang Antara Metode Konseling Dengan Leflet Di Puskesmas Bengkunat, Kabupaten Pesisir Barat. Jurnal Dunia Kesmas, 6(3).

Octa Reni Setiawati' Fakultas Psikologi Universitas Malahayati Bandar Lampung. Email: ores.survive@gmail.com Nurseha ${ }^{2}$ Unit Promosi Kesehatan Rumah Sakit (PKRS) Rumah Sakit Umum Daerah dr H. Bob Bazar SKM Kabupaten Lampung Selatan. Email: nursehaskm@ymail.com

Teguh Pribadi ${ }^{3}$ Fakultas Kedokteran Program Studi llmu Keperawatan Universitas Malahayati Bandar Lampung Email: teguh@malahayati.ac.id 